Dicle University Journal of Engineering (DUJE)

web: http://dergipark.gov.tr/dumf

Araştırma Makalesi / Research Article

\title{
Aşağı Seyhan Ovası (Mersin-Adana) Yeraltı ve Yüzey Sularının Çeşitli Grafik Yöntemlerle Sınıflandırılması
}

\section{Classification of Ground and Surface Waters of Lower Seyhan Plain (Mersin- Adana) by Various Graphical Methods}

\section{Can AKBULUT CAMUZCUOĞLU ${ }^{*}$, Cüneyt GÜLER ${ }^{2}$}

${ }^{1}$ Mersin Üniversitesi, Yapı İşleri ve Teknik Daire Başkanlığı, Mersin, canakbulut@mersin.edu.tr

${ }^{2}$ Mersin Üniversitesi, Jeoloji Mühendisliği Bölümü, Mersin, cguler@mersin.edu.tr

\begin{tabular}{l} 
MAKALE BİLGİLERİ \\
\hline Makale geçmişi: \\
Geliş: 30 Aralık 2019 \\
Düzeltme: 20 Nisan 2020 \\
Kabul: 4 Mayıs 2020 \\
\hline Anahtar kelimeler: \\
Yeraltı suyu, yüzey suyu, \\
hidrojeokimya, su kalitesi, Aşağ1 \\
Seyhan Ovası
\end{tabular}

\section{ÖZET}

Bu çalışma, Türkiye'nin Doğu Akdeniz kıyısında bulunan Çukurova Deltası'nın yaklaşık olarak 2125 km²'lik bir kesimini kapsayan Aşağı Seyhan Ovası'nda (ASO) yapılmıştır. Sanayi ve evsel kaynaklı atıksuların herhangi bir arıtım işlemine tabi tutulmadan su kaynaklarına boşaltılması ve yoğun tarımsal faaliyetler bu bölgede içmekullanma suyu olarak kullanılan yeraltı ve yüzey sularının kalitesini olumsuz yönde etkilemektedir. Bu çalışma kapsamında, ASO'nda bulunan yeraltı ve yüzey sularının kalitelerinin ve hidrojeokimyasal özelliklerinin belirlenmesi amacıyla Haziran-Temmuz 2014 döneminde bölgedeki kuyulardan ve çeșitli yüzey sularından (Akdeniz, Seyhan ve Berdan nehirleri, sulama ve drenaj kanalları, Tuzla ve Akyatan lagünleri) toplam 173 adet su örneği alınmıştır. Alınan su örnekleri üzerinde, yerinde (arazide) yapılan çeşitli fiziksel parametrelere (pH, Eh ve elektriksel iletkenlik) ait ölçümlerin yanı sıra, laboratuvarda çeşitli majör iyonlara $\left(\mathrm{Ca}^{+2}, \mathrm{Mg}^{+2}, \mathrm{Na}^{+}, \mathrm{K}^{+}\right.$, $\mathrm{CO}_{3}^{-2}, \mathrm{HCO}_{3}^{-}, \mathrm{Cl}^{-}, \mathrm{SO}_{4}^{-2}, \mathrm{NO}_{3}^{-}, \mathrm{NO}_{2}^{-}, \mathrm{NH}_{4}^{+}, \mathrm{PO}_{4}^{-3}$ ve $\mathrm{F}^{-}$) ait konsantrasyon değerleri spektrometrik, spektrofotometrik ve titrimetrik analiz yöntemleriyle belirlenmiştir. $\mathrm{Bu}$ ölçüm ve analiz sonuçlarından elde edilen veriler kullanılarak Piper, Durov, Yarı Logaritmik Schoeller, ABD Tuzluluk Laboratuvarı ve Wilcox diyagramları oluşturularak değerlendirmeler yapılmıştır. Bölgede mevcut değişik türlerdeki suların farklı karakterlere sahip olduğu ve fizikokimyasal değerlerin geniş bir aralıkta değiştiği sonucuna varılmıştır.

Doi: $10.24012 /$ dumf. 666078

\begin{tabular}{l} 
ARTICLE INFO \\
\hline Articlehistory: \\
Received: 30 December 2019 \\
Revised: 20 April 2020 \\
Accepted: 4 May 2020 \\
\hline Keywords:
\end{tabular}

Groundwater, surface water, hydrogeochemistry, water quality, Lower Seyhan Plain

\begin{abstract}
This study was carried out in the Lower Seyhan Plain (LSP), which covers an area of approximately $2125 \mathrm{~km}^{2}$ in the Çukurova Delta, located in the Eastern Mediterranean coast of Turkey. Discharge of wastewaters from industrial and domestic sources to water resources without any treatment process and intense agricultural activities adversely affect the quality of groundwater and surface waters, which are used as drinking/potable water sources in the region. Within the scope of this study, a total of 173 water samples were collected from wells and various surface waters (Mediterranean Sea, Seyhan and Berdan rivers, irrigation and drainage canals, Tuzla and Akyatan lagoons) in the region between June and July 2014 in order to determine the quality and hydrogeochemical properties of groundwater and surface waters in the LSP. In addition to the measurements of various physical parameters ( $\mathrm{pH}, \mathrm{Eh}$ and electrical conductivity) made on site, concentration values of various major ions $\left(\mathrm{Ca}^{2+}, \mathrm{Mg}^{2+}, \mathrm{Na}^{+}, \mathrm{K}^{+}, \mathrm{CO}_{3}{ }^{2-}, \mathrm{HCO}_{3}{ }^{-}, \mathrm{Cl}^{-}, \mathrm{SO}_{4}{ }^{2-}, \mathrm{NO}_{3}{ }^{-}, \mathrm{NO}_{2}{ }^{-}, \mathrm{NH}_{4}{ }^{+}, \mathrm{PO}_{4}{ }^{3-}\right.$ and $\left.\mathrm{F}^{-}\right)$were determined in the laboratory by spectrometric, spectrophotometric and titrimetric analysis methods. The results obtained from measurements and analyses were used to create and interpret Piper, Durov, Semi-Logarithmic Schoeller, USA Salinity Laboratory and Wilcox diagrams. It is concluded that different types of waters present in the region are diverse in character and physicochemical values vary within a wide range.
\end{abstract}

\footnotetext{
* Sorumlu yazar / Correspondence

Can AKBULUT CAMUZCUOĞLU

$\triangle$ canakbulut@mersin.edu.tr
} 


\section{Giriş}

Türkiye, yaşamın vazgeçilmez unsurlardan olan su kaynakları açısından önemli bir potansiyele sahiptir. Ancak, artan nüfusa bağlı olarak gelişen endüstriyel ve tarımsal faaliyetler, su kaynakları üzerinde hem miktar hem de kalite açısından önemli bir baskı oluşturmaktadır. İçme-kullanma ve sulama suyuna olan talebin her geçen gün arttığı göz önüne alındığııda, kaynakların etkin ve doğru bir şekilde kullanımıyla beraber, sürdürülebilir kullanıma yönelik hidrojeolojik ve hidrojeokimyasal çalışmaların yapılması gerekmektedir [1-5].

Çalışma alanı olarak belirlenen bölge, yerleşimin, sanayi ve tarımsal faaliyetlerin birlikte görüldüğü Aşağı Seyhan Ovası'nı kapsamaktadır (Şekil 1). Seyhan Nehri tarafından ikiye bölünen Aşağı Seyhan Ovası'nın, Seyhan Nehri ile Tarsus Çayı (Berdan Nehri) arasında kalan kısmı "Seyhan Sağ Sahil" veya "Tarsus Ovası" olarak, Ceyhan Nehri ile Seyhan Nehri arasında kalan kısmı ise "Seyhan Sol Sahil" veya "Yüreğir Ovası" olarak isimlendirilmektedir [6-8]. Bölgede, bu ovaların sulama ihtiyacının karşılanması için yapılmış çok sayıda sulama kanalı ve ayrıca sulamadan dönen tarımsal suların toplanması için yapılmış drenaj kanalları bulunmaktadır. Ayrıca, zamanla artan nüfus ve gelişen sanayi, Seyhan Nehri'nin yerleşim merkezi sınırları içerisinde kalmasına neden olmuştur. Seyhan Nehri'ne ve drenaj kanallarına Adana ili ve civarındaki pek çok yerleşim yerinden evsel ve endüstriyel atıksu deşarjları yapılmaktadır. Bu nedenle, nehir ve yeraltı suyu kalitesi tarımsal faaliyetlerin yanı sıra evsel atıklar ve endüstriyel faaliyetlerden de olumsuz olarak etkilenmektedir $[6,9,10]$. Bu bağlamda, su kaynaklarının kalitesini belirleyebilmek için çeşitli fizikokimyasal parametreler analiz edilmiş ve elde edilen sonuçlarla çeşitli değerlendirmeler yapılmıştır.

\section{Materyal ve Yöntem}

\section{Yeraltı ve yüzey suyu örneklemeleri}

Bu çalışma kapsamında, Haziran-Temmuz 2014 döneminde ovadaki su kaynaklarından toplam 173 adet su örneği alınmıştır. Bunlardan 132'si kuyulardan, 5'i nehirlerden (Seyhan ve Berdan), 31'i sulama ve drenaj kanallarından, 2'si
Akdeniz'den, 3'ü ise Tuzla ve Akyatan lagünlerinden alınmıştır (Şekil 2). Kuyulardan alınan su örneklerinin arazi şartlarını karakterize etmesi açısından örneklemeler, kuyu hacminin üç katı kadar miktarda su pompalandıktan sonra yapılmıştır. Yüzey sularından alınan örnekler ise kiyıdan en fazla $50 \mathrm{~cm}$ mesafeden ve su yüzeyinden $30 \mathrm{~cm}$ derinliğe örnek şişelerinin daldırılması yoluyla alınmıştır. Alınan örneklerde yerinde çeşitli fiziksel parametrelere ( $\mathrm{pH}$, Eh ve elektriksel iletkenlik) ait ölçümler WTW Multi 340i/SET marka portatif multiparametre cihazı ile tayin edilmiştir. Her örnekleme noktasında ikişer adet $250 \mathrm{~mL}$ kapasiteli yüksek yoğunluklu polietilen (HDPE) plastik şişeler kullanılmıştır. $\mathrm{Bu}$ şişelerden birine, katyonların şişeye absorbe olmasını veya çökelmesini önlemek amacıyla $\mathrm{pH}<2$ olacak şekilde nitrik asit $\left(\mathrm{HNO}_{3}\right)$ ilave edilmiştir.

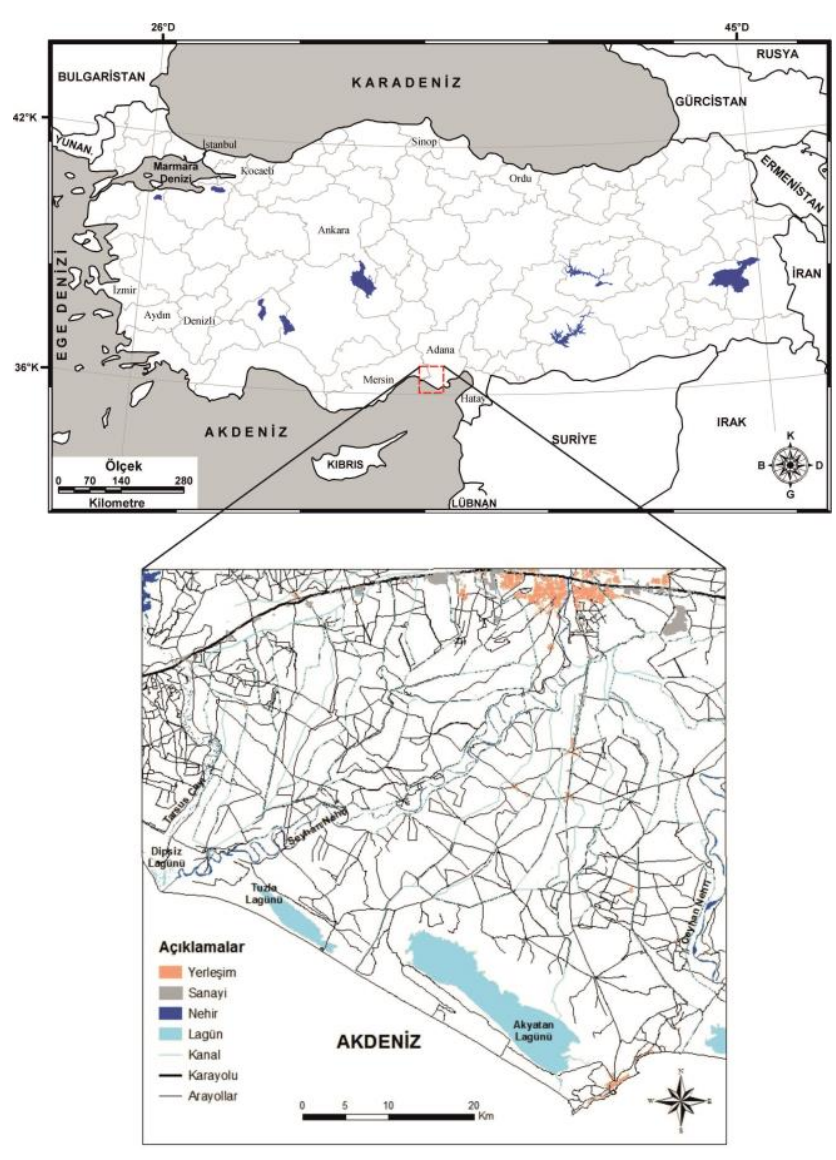

Şekil 1. Inceleme alanının yer bulduru haritası [5].

Alınan su örnekleri, buharlaşma etkilerini azaltmak açısından laboratuvara bir buzlukta 
taşınmış ve analizler yapılıncaya kadar soğutucuda $+4^{\circ} \mathrm{C}$ 'de muhafaza edilmiştir.

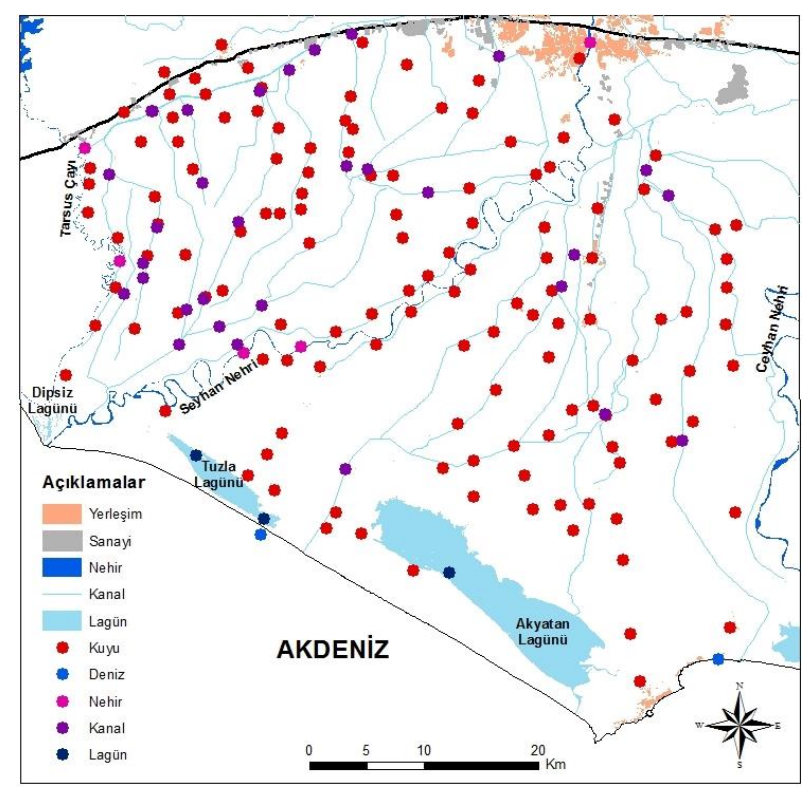

Şekil 2. Yeraltı ve yüzey suyu örnekleme noktalart.

\section{Analitik prosedür}

Alınan su örneklerine ait 4 majör katyonun $(\mathrm{Ca}$, $\mathrm{Mg}, \mathrm{Na}$ ve K) konsantrasyonlar1 Mersin Üniversitesi İleri Teknoloji Eğitim, Araştırma ve Uygulama Merkezinde (MEITAM) bulunan Agilent 7500ce marka ICP-MS cihazı ile ölçülmüştür. Ayrıca, kontrol amaçlı olarak, Çukurova Üniversitesi Jeoloji Mühendisliği Bölümünde bulunan Perkin Elmer 700 model Atomik Absorpsiyon Spektrometresi kullanılarak da ölçümler yapılmıştır. Klorür, sülfat, nitrat, nitrit, fosfat ve florür konsantrasyonları ise Hach Lange DR2800 marka spektrofotometre ile tayin edilmiştir. Karbonat ve bikarbonat konsantrasyonları ise EPA 310.1'e göre titrasyon yöntemiyle saptanmıştır.

\section{Bulgular}

\section{Jeoloji ve hidrojeoloji}

Birbirinden farklı ve çok sayıda litolojik birimin yer aldığ1 bölgede, Oligosen-Pliyosen zaman aralığında çökelen sedimanter kayaçlarla temsil edilen Tersiyer birimleri, Toros orojenik kuşağını oluşturan Paleozoyik-Mesozoyik yaşı temel kayaçların oluşturduğu engebeli topoğrafya üzerine uyumsuz olarak gelmektedir $[11,12]$. Bu birimleri de, çoğunlukla karasal bir fasiyeste çökelen, gevşek tutturulmuş veya tutturulmamış, kaba akarsu konglomeraları, kumtaşları, kil ve siltlerden oluşan Kuranşa formasyonu üzerlemektedir [13-15] (Şekil 3).

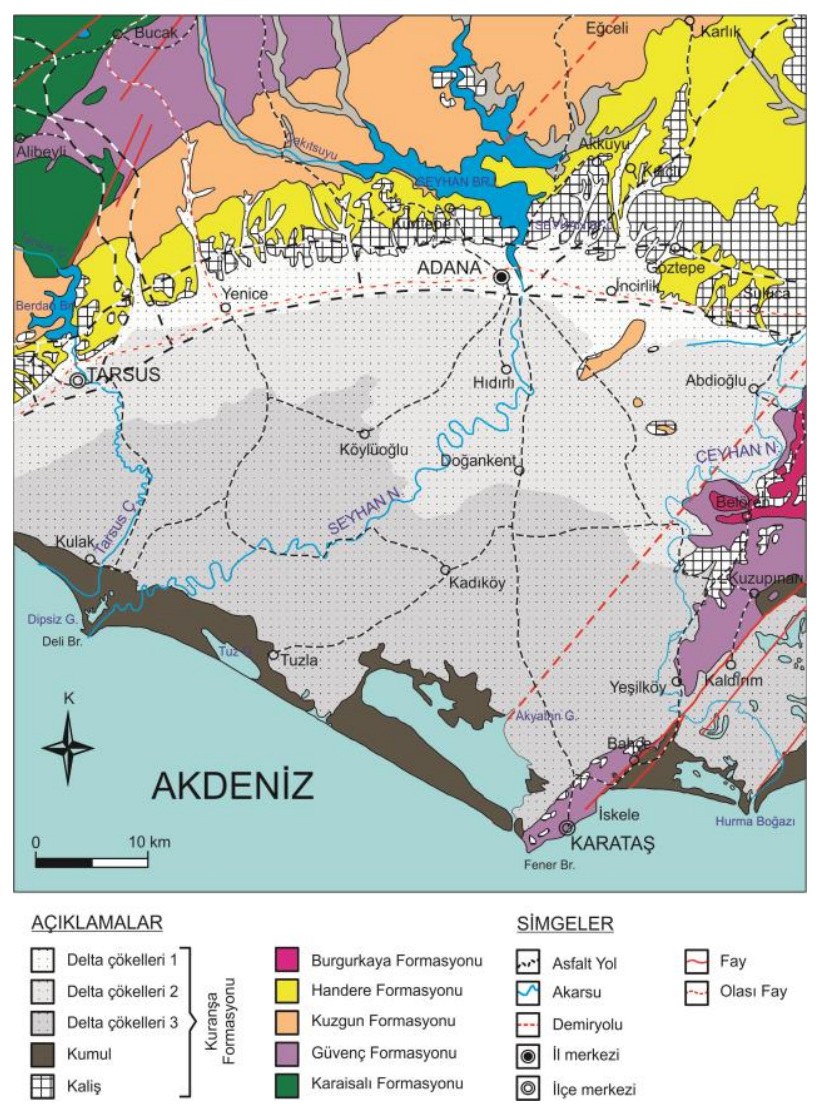

Şekil 3. Çalışma alanı ve çevresinin jeoloji haritası (MTA, 2002'den değiştirilerek) [16].

Siciliyen sonlarında Adana bölgesinde meydana gelen çöküntü alanlarının, daha sonra oluşan akarsu ve kolları tarafindan getirilen materyallerle dolması sonucu delta çökelleri birikmiştir. $\mathrm{Bu}$ çökeller Şenol vd. [17] tarafından stratigrafik olarak alttan üste ve karadan denize doğru Delta çökelleri 1, Delta çökelleri 2, Delta çökelleri 3 olarak üçe farklı fasiyese ayrılmıştır.

Yakın tarihte ve günümüzde, kıyıda esen şiddetli rüzgârların etkisi ile kıyıdaki kumların onlarca metre içerilere kadar taşınması sonucu bölgede kıyı kumulları oluşmuştur. Kumulların kaynak kayaları Miyosen öncesi metamorfikler, magmatikler, ofiyolitler, Neojen ve daha genç birimler olmakla birlikte, genellikle 
ofiyolitlerden türeyen minerallerin egemen olduğu görülmektedir [17].

Çalışma alanının şekillenmesinde etkili olan nehirlerin başında, toplam uzunluğu $560 \mathrm{~km}$, en düşük debisi $31 \mathrm{~m}^{3} / \mathrm{s}$ olan Seyhan Nehri gelmektedir. Çalışma alanının doğu sınırını oluşturan Ceyhan Nehri'nin ise toplam uzunluğu $509 \mathrm{~km}$ olup, ortalama debisi 180 $\mathrm{m}^{3} / \mathrm{s}$ 'dir [18]. Ovanın şekillenmesine nispeten daha az katkısı olan ve çalışma alanının batı sınırını oluşturan Tarsus Çayı (Berdan Nehri) ise $124 \mathrm{~km}$ uzunluğa sahip olup ortalama debisi $39,5 \mathrm{~m}^{3} / \mathrm{s}$ 'dir [19].

Seyhan Nehri'nin ana kolu üzerinde, Adana ilinin kuzeyinde Seyhan Barajı ve Hidroelektrik Santralı bulunmaktadır. Barajın kuzeyinde ise Adana'nın içme ve kullanma suyunu sağlayan Çatalan Barajı yer almaktadır. Seyhan Barajı'nın hemen güneyinde bulunan Seyhan Regülatöründen, Tarsus (Seyhan Sağ Sahil) ve Yüreğir (Seyhan Sol Sahil) ovalarına ana kanallarla ortalama $130 \mathrm{~m}^{3} / \mathrm{s}$ debiyle sulama suyu iletilmektedir. Derinlikleri $1,5 \mathrm{~m}$ ile $6 \mathrm{~m}$ arasında değişen drenaj kanallarına sulama kanallarından bağlantı bulunmaktadır. Ayrıca ovada bulunan sanayi kuruluşlarından ortalama 30-40 L/s miktarındaki atıksu drenaj kanallarına boşaltılmaktadır [20].

İçme-kullanma ve sulama suyu ihtiyacını karşılamak üzere DSİ (Devlet Su İşleri) ve YSE (Yol, Su ve Elektrik İşleri Genel Müdürlüğü) tarafindan bölgede çok sayıda sondaj kuyusu açılmıştır. Şahıslar tarafından açılan kuyular da dâhil olmak üzere bölgede yaklaşık olarak 500 adet sondaj kuyusunun bulunduğu söylenebilir.

Çalışma alanı sınırları içerisinde batıdan doğuya doğru Dipsiz, Tuzla, Akyatan ve Ağyatan Lagün sistemleri gözlenmektedir. Bunlar, deltanın şekillenmesinde etkili olan Seyhan ve Ceyhan nehirlerinin taşımış olduğu çökellerin rüzgâr ve dalgalarla kıyıya paralel olarak taşınması ve oluşturdukları kum tepeleri ile kara arasındaki çukurluklara deniz sularının dolması ile oluşmuşlardır [18, 21].

Çalışma alanındaki akifer litolojisi oldukça heterojen bir yapıya sahip olup tipik bir kıyı akiferi karakteri sergilemektedir.

\section{Hidrojeokimya}

Havza bazında yapılan hidrojeolojik araştırmalarda benzer özellikteki suların değerlendirilmesi veya suların hidrojeokimyasal evrim süreçlerinin açılanabilmesi ve bu değerlendirmelerin görsel olarak sunulabilmesi için, kimyasal analiz sonuçları uygun grafiklere aktarılarak yorumlamalar yapılır [5]. Bu çalışma kapsamında, analiz sonuçları çeşitli diyagramlar (Piper, Durov, Yarı Logaritmik Schoeller, ABD Tuzluluk Laboratuvarı ve Wilcox) [22-26] üzerinde değerlendirilerek sınıflandırılmış ve tanımlamalar yapılmıştır.

Çalışma alanından alınan yeraltı suları Piper diyagramında değerlendirildiğinde, Tarsus Ovası'ndan alınan yeraltı sularının yoğunluklu olarak karbonat sertliği \%50'den fazla olan, toprak alkalilerin $\left(\mathrm{Ca}^{+2}+\mathrm{Mg}^{+2}\right)$ alkalilerden $\left(\mathrm{Na}^{+}+\mathrm{K}^{+}\right)$, zayıf asit köklerinin $\left(\mathrm{CO}_{3}{ }^{-2}+\mathrm{HCO}_{3}{ }^{-}\right)$ de güçlü asit köklerinden $\left(\mathrm{SO}_{4}{ }^{-2}+\mathrm{Cl}^{-}\right)$daha fazla olduğu 5. bölgede, Yüreğir Ovası'ndan alınan yeraltı sularının ise daha çok iyonlarının hiçbirinin \%50'yi geçmediği, karışık suların bulunduğu 9. bölgede olduğu gözlenmiştir (Şekil 4, Şekil 5).
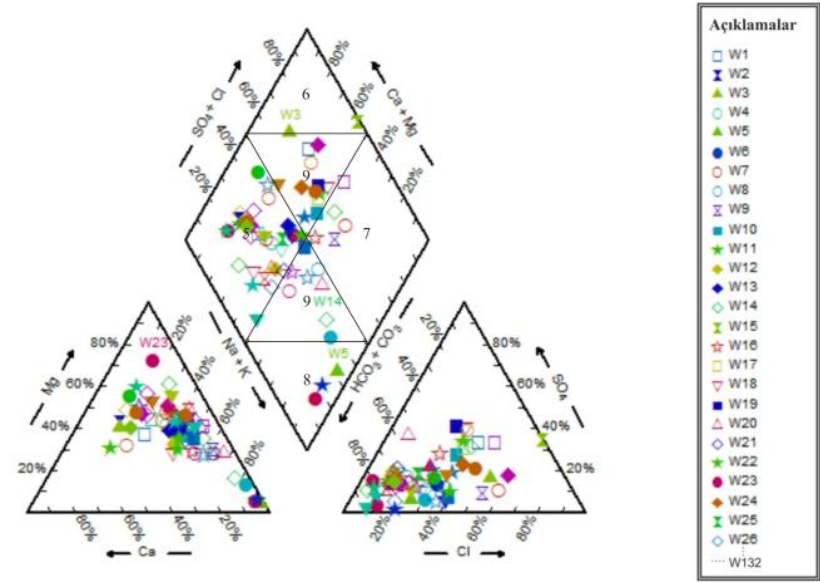

Şekil 4. Tarsus Ovası'ndan alınan yeraltı suyu örneklerinin Piper diyagramındaki dağılımı [5]. 

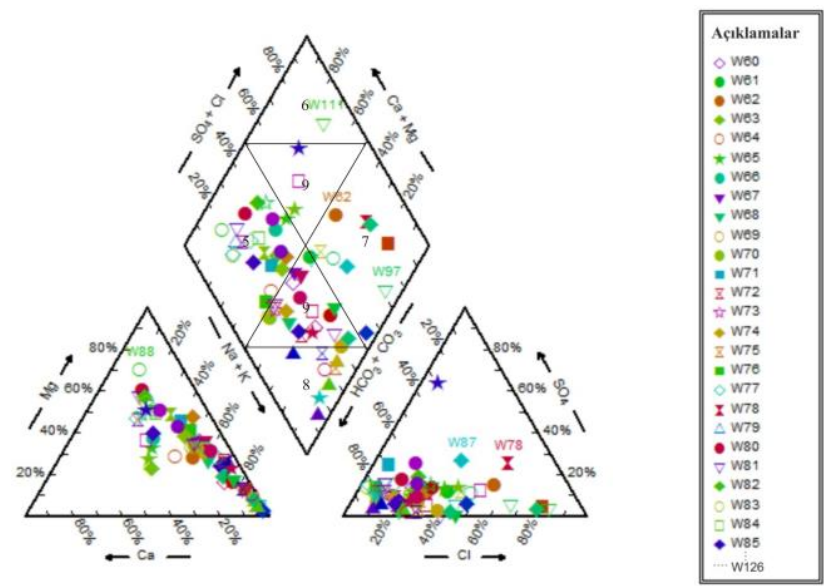

Şekil 5. Yüreğir Ovası'ndan alınan yeraltı suyu örneklerinin Piper diyagramındaki dağılımı [5].

Akdeniz'den ve lagünlerden (Tuzla ve Akyatan) alınan sular karbonat olmayan sertliğin \%50'den fazla olduğu, alkalilerin $\left(\mathrm{Na}^{+}+\mathrm{K}^{+}\right)$toprak alkalilerden $\left(\mathrm{Ca}^{+2}+\mathrm{Mg}^{+2}\right)$, güçlü asit köklerinin $\left(\mathrm{SO}_{4}{ }^{-2}+\mathrm{Cl}^{-}\right)$de zayıf asit köklerinden $\left(\mathrm{CO}_{3}{ }^{-2}+\mathrm{HCO}_{3}{ }^{-}\right)$daha fazla olduğu 7. bölgede, $\mathrm{NaCl}$ su tipindedir (Şekil 6, Şekil 7).

Nehirlerden (Berdan ve Seyhan) alınan sular ise karbonat sertliği \%50'den fazla olan (5. bölge) su tipindedir (Şekil 8).
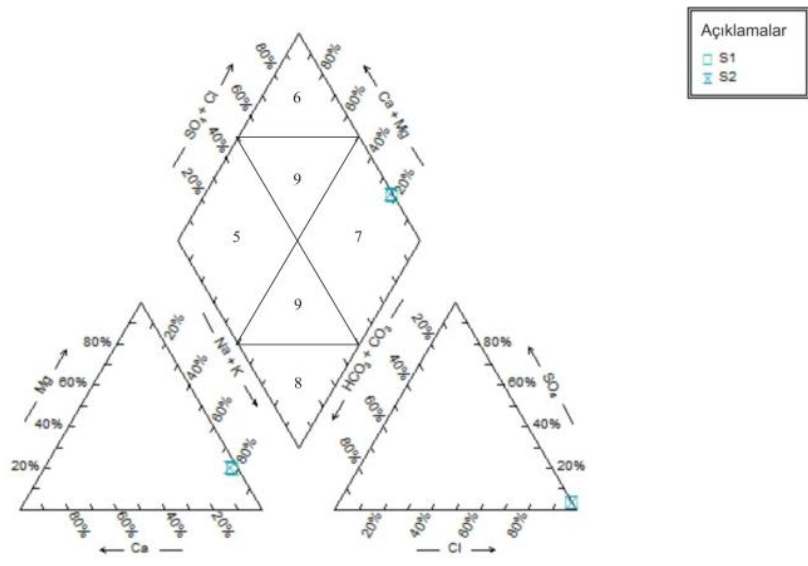

Şekil 6. Akdeniz'den alınan su örneklerinin Piper diyagramındaki dağılımı [5].
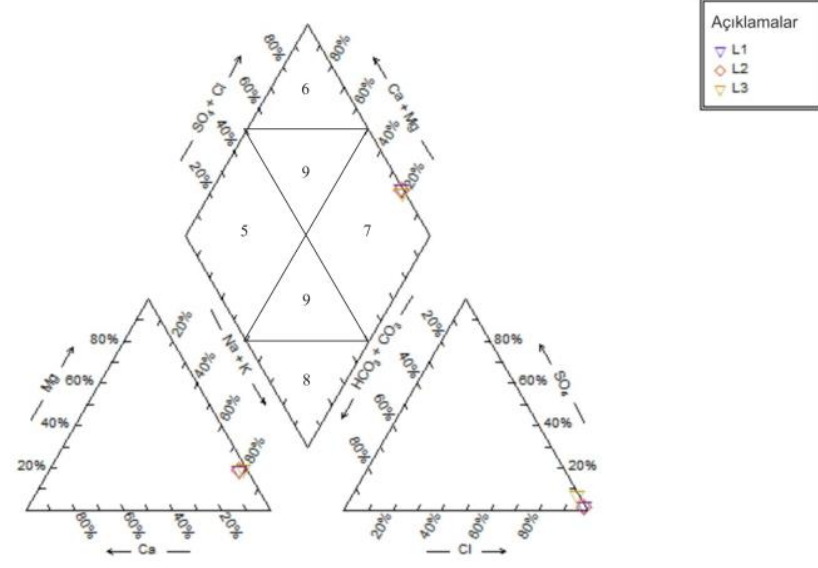

Şekil 7. Lagünlerden (Tuzla ve Akyatan) alınan su örneklerinin Piper diyagramındaki dağılımı [5].
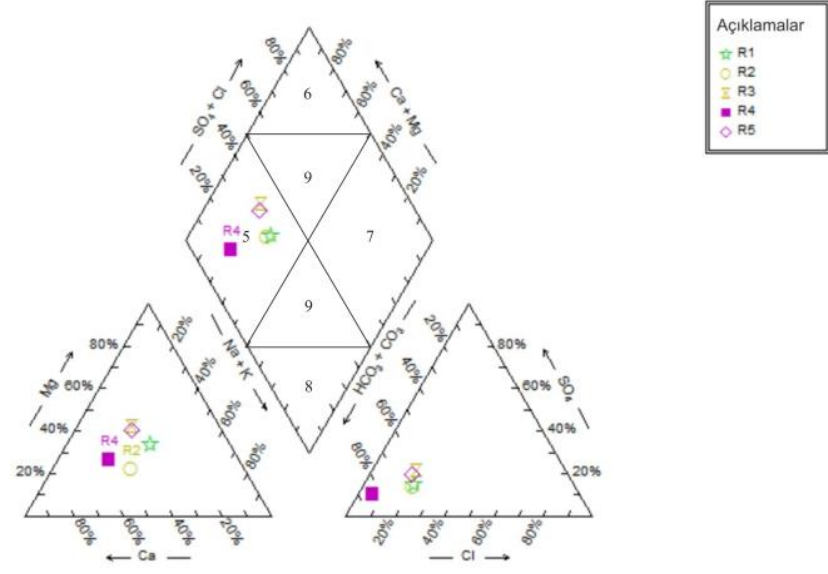

Şekil 8. Nehirlerden (Berdan ve Seyhan) alınan su örneklerinin Piper diyagramındaki dă̆ılımı [5].

Kanallardan alınan suların Piper diyagramındaki konumlarına bakıldığında ise üç kanalın baskın iyon içermeyen karışık su tipinde olduğu, geri kalanların ise karbonat sertliği \%50'den fazla olan 5. bölgede olduğu gözlenmiştir (Şekil 9).

Çalışma alanından alınan yeraltı suları, Tarsus ve Yüreğir ovaları için oluşturulan iki ayrı Durov diyagramında değerlendirilmiştir (Şekil 10, Şekil 11). Tarsus Ovası yeraltı sularının toplam çözünmüş madde (TÇM) miktarları 266,2-7052,1 $\mathrm{mg} / \mathrm{L}$ arasında, $\mathrm{pH}$ değerleri ise 7,19-8,64 arasında değişmektedir. Yüreğir Ovası yeraltı sularının TÇM miktarları 270,92637,4 $\mathrm{mg} / \mathrm{L}$ arasinda, $\mathrm{pH}$ değerleri ise 7,118,73 arasında değişmektedir. Aşağı Seyhan Ovası'ndan alınan W15 nolu örnek haricindeki bütün yeraltı suyu örneklerinin TÇM 
miktarlarının ve $\mathrm{pH}$ değerlerinin yaklașık olarak birbirine yakın olduğu gözlenmiștir.
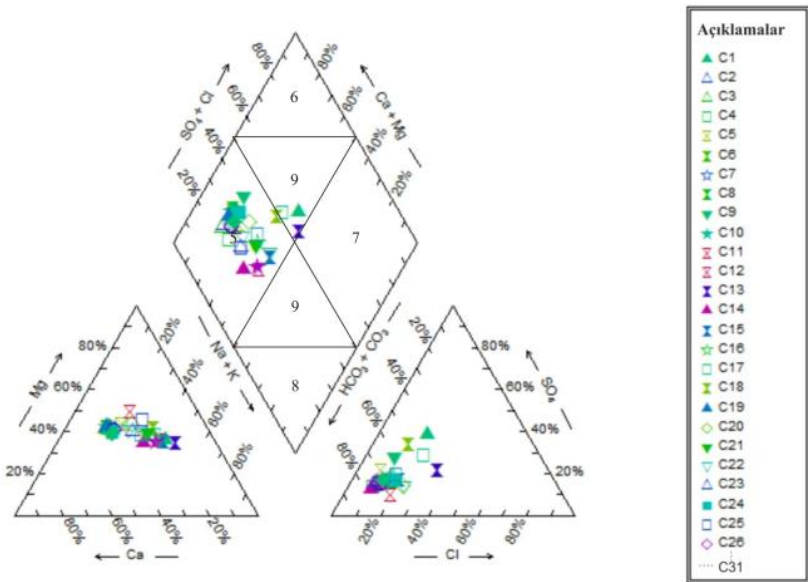

Şekil 9. Kanallardan alınan su örneklerinin Piper diyagramındaki dăğlımı [5].
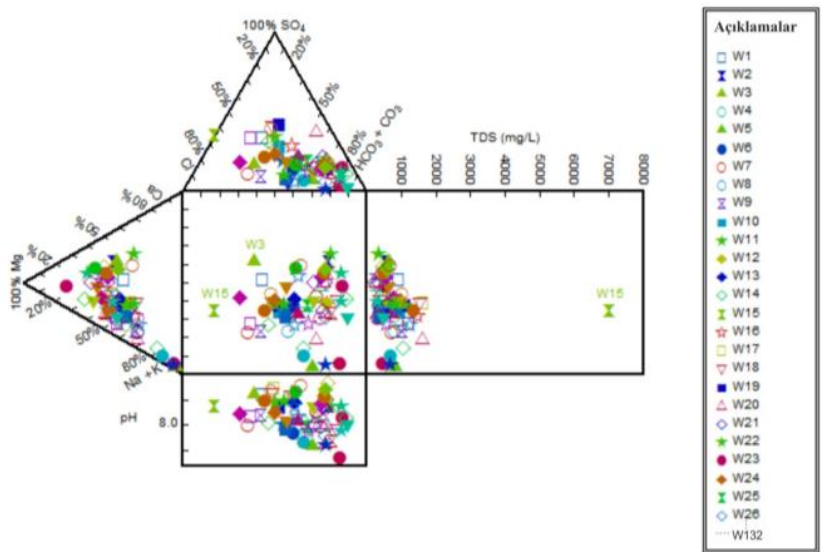

Şekil 10. Tarsus Ovası'ndan alınan yeraltı suyu örneklerinin Durov diyagramındaki dağılımı [5].

Durov diyagramına yerleştirilen Akdeniz ve lagün (Tuzla ve Akyatan) suları için ana katyonun $\mathrm{Na}^{+}$, anyonun ise $\mathrm{Cl}^{-}$olduğu görülmektedir (Şekil 12, Şekil 13). Akdeniz'den alınan örneklerin TÇM miktarları 36077,9 ve $36656,5 \mathrm{mg} / \mathrm{L}$ iken, $\mathrm{pH}$ değerleri 7,96 ve 8,01'dir. Lagünlerden alınan örneklerin TÇM miktarlar1 48353,1 ile 97253,6 mg/L arasında, $\mathrm{pH}$ değerleri ise 7,92 ile 8,75 arasında değişim göstermektedir.

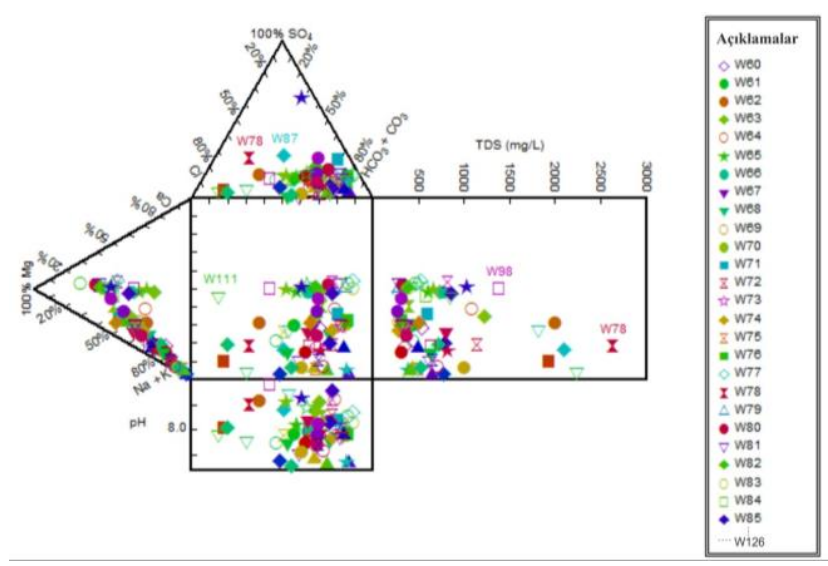

Şekil 11. Yüreğir Ovası'ndan alınan yeraltı suyu örneklerinin Durov diyagramındaki dağılımı [5].
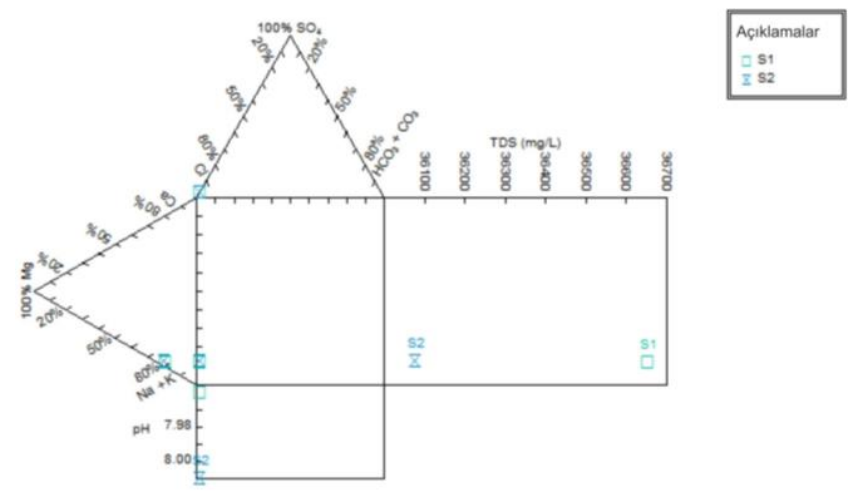

Şekil 12. Akdeniz'den alınan su örneklerinin Durov diyagramındaki dağılımı [5].

Nehirlerden (Berdan ve Seyhan) ve kanallardan alınan örneklerin Durov diyagramındaki dağılımları incelendiğinde, sularda katyonlar açısından hâkim iyonların değişken olduğu, anyonlar açısından ise hakim iyonun $\mathrm{HCO}_{3}{ }^{-}$ olduğu gözlenmiştir. Nehirlerden alınan suların toplam TÇM miktarları 246,7-421,6 mg/L, pH değerleri ise 8,06-8,46 arasında değişmektedir (Şekil 14). Kanallardan alınan suların ise toplam TÇM miktarları 278,7-794,5 mg/L, pH değerleri ise 7,68-8,14 arasında değişmektedir (Şekil 15). 

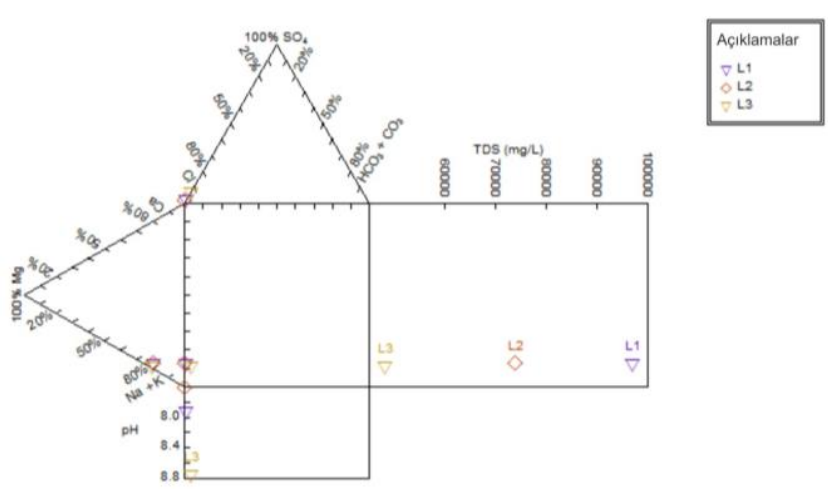

Şekil 13. Lagünlerden (Tuzla ve Akyatan) alınan su örneklerinin Durov diyagramındaki dağılımı [5].
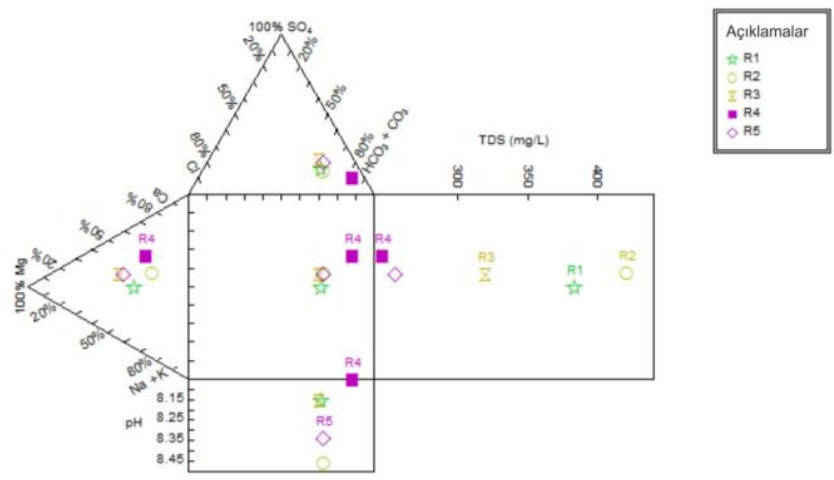

Şekil 14. Nehirlerden (Berdan ve Seyhan) alınan su örneklerinin Durov diyagramındaki dă̆ılımı [5].
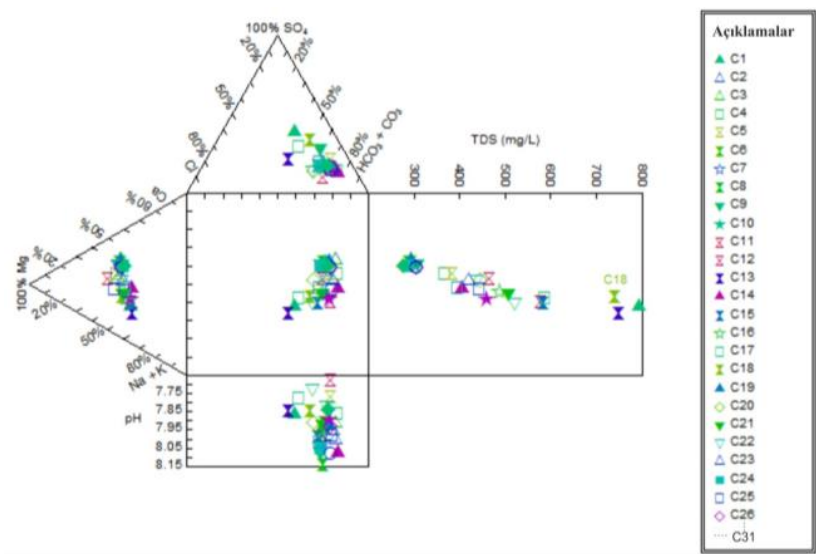

Şekil 15. Kanallardan alınan su örneklerinin Durov diyagramındaki dă̆glımı [5].

Çalışma alanından alınan yeraltı suları, Tarsus ve Yüreğir ovaları için oluşturulan iki ayrı Schoeller diyagramında değerlendirilmiştir (Şekil 16, Şekil 17). Diyagramlarda benzer kökenli, aynı hazneye ve beslenme alanına sahip olan sular benzer pik değerler vermektedir. Tarsus Ovası'ndan alınan W15 nolu örnek, hem iyon içeriklerinin yüksek olması hem de $\mathrm{HCO}_{3}{ }^{-}+\mathrm{CO}_{3}{ }^{-2}$ ve $\mathrm{Cl}^{-}$içeriklerinin havza geneline göre belirgin farklılıklar göstermesi ile ayırt edilebilmektedir (Şekil 16). Ayrıca ovalardan alınan bazı suların diğer sular ile benzer paralelliğe sahip olmadığı, bu suların dolaşım sürecinin fazla olması nedeniyle aynı akiferde dolaşan diğer sulara göre bazı iyonlarca farklı miktarda zenginleştiği gözlenmiştir (Şekil 16, Şekil 17).

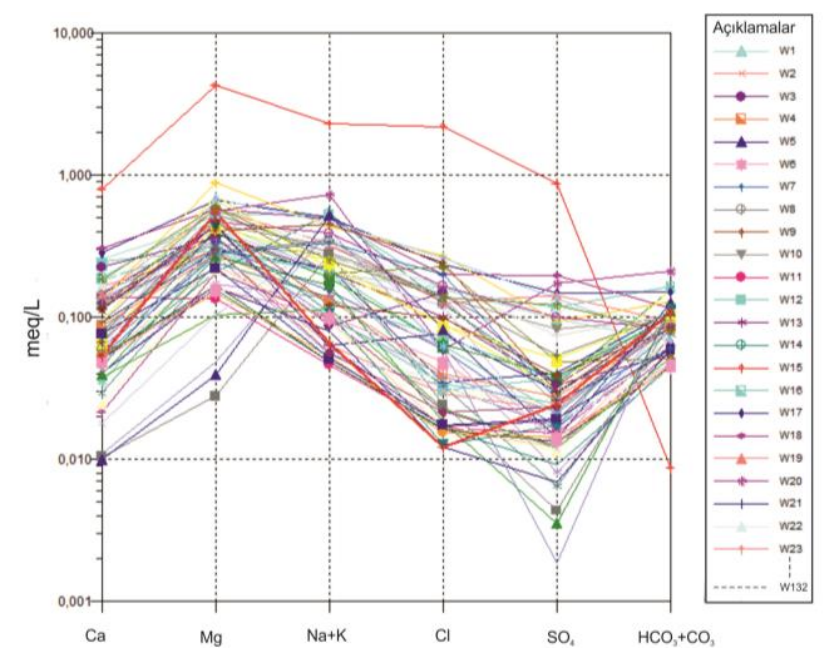

Şekil 16. Tarsus Ovası'ndan alınan yeraltı suyu örneklerinin Yarl Logaritmik Schoeller diyagramındaki dă̆ılımı [5].

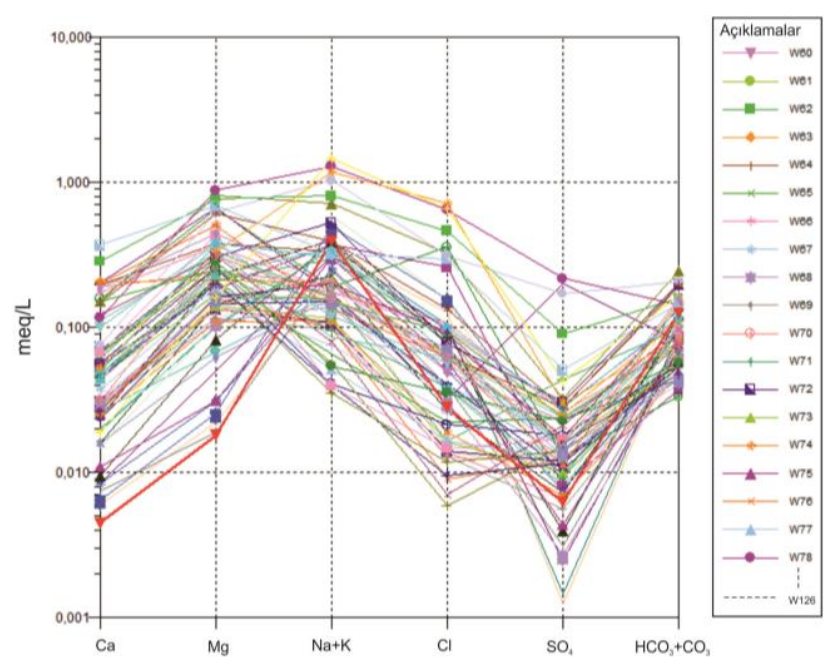

Şekil 17. Yüreğir Ovası'ndan alınan yeraltı suyu örneklerinin Yart Logaritmik Schoeller diyagramındaki dağılımı [5]. 
Akdeniz'den ve lagünlerden (Tuzla ve Akyatan) alınan suların benzer özellikler taşıdıkları ve yarı logaritmik diyagram üzerinde paralel bir dizilim gösterdikleri gözlenmiştir (Şekil 18, Şekil 19). Nehirlerden alınan örnekler ile kanallardan alınan 18 örnek, $\mathrm{Ca}^{+2}$ ve $\mathrm{Na}^{+}+\mathrm{K}^{+}$ içeriklerinin diğer örneklere göre belirgin farklılıklar göstermesi ile ayırt edilebilmektedir (Şekil 20, Şekil 21).

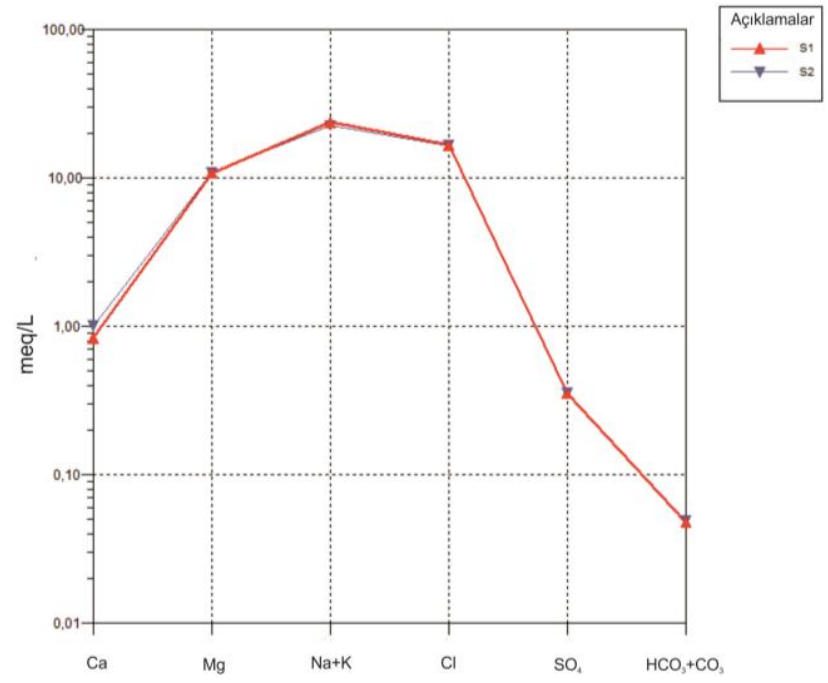

Şekil 18. Akdeniz'den alınan su örneklerinin Yarı Logaritmik Schoeller diyagramındaki dă̆ılımı [5].

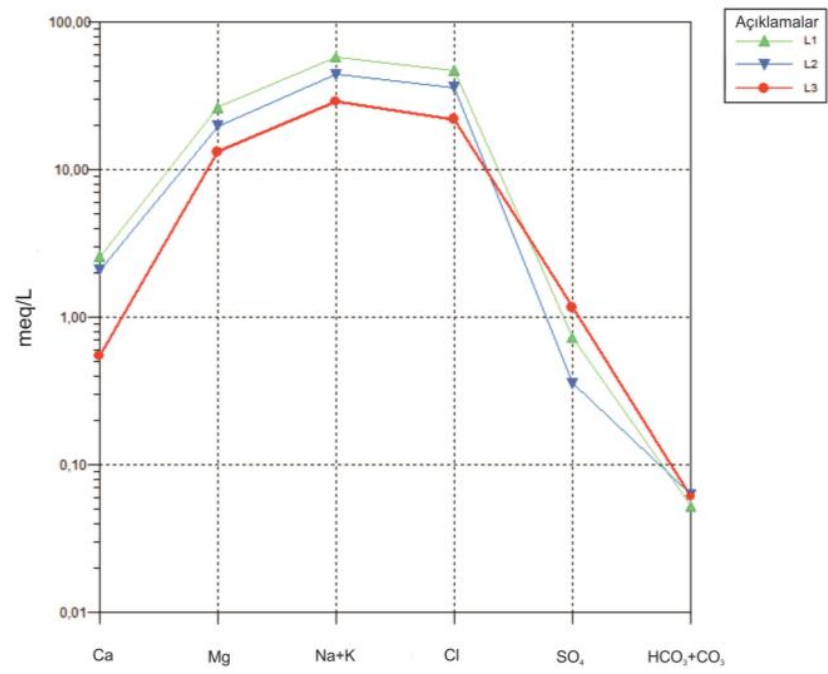

Şekil 19. Lagünlerden (Tuzla ve Akyatan) alınan su örneklerinin Yarı Logaritmik Schoeller diyagramındaki dă̆ılımı [5].

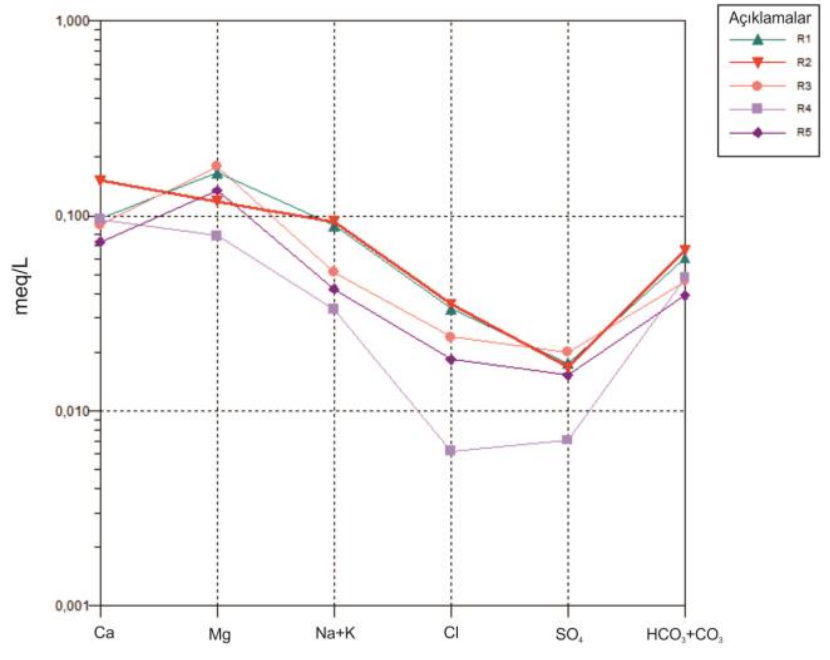

Şekil 20. Nehirlerden (Berdan ve Seyhan) alınan su örneklerinin Yar Logaritmik Schoeller diyagramındaki dağılımı [5].

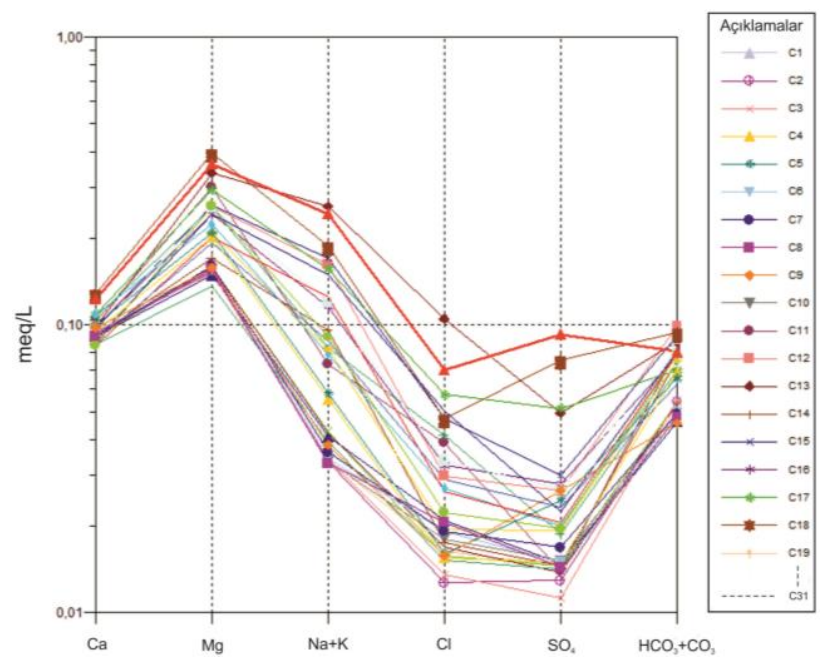

Sekil 21. Kanallardan alınan su örneklerinin Yarl Logaritmik Schoeller diyagramındaki dă̆ılımı [5].

Çalışma alanından alınan yeraltı ve yüzey sularının sulama suyu olarak kullanılabilirliği, oluşturulan ABD Tuzluluk Laboratuvarı diyagramı yardımıyla değerlendirilmiştir (Şekil 22). Tarsus Ovası'ndan alınan yeraltı sularının SAR (Sodyum Adsorbsiyon Oranları) değerleri 0,69-20,44 arasında, EC değerleri ise 389-5930 $\mu \mathrm{S} / \mathrm{cm}$ arasında değişmektedir. Yüreğir Ovası'ndan alınan yeraltı sularının SAR değerleri 0,49-30,99 arasında, EC değerleri ise $387-4010 \mu \mathrm{S} / \mathrm{cm}$ arasında değişmektedir. Tarsus Ovası'ndan alınan W15 nolu örneğin elektriksel iletkenlik değeri $(\mathrm{EC}>5000 \mu \mathrm{S} / \mathrm{cm})$ yüksek 
olduğu için ABD Tuzluluk Laboratuvarı diyagramına yerleştirilememiştir (Şekil 22).

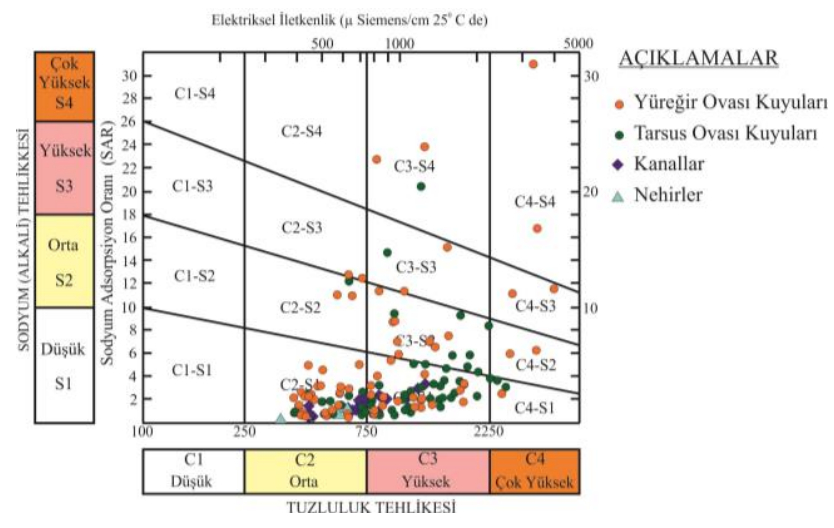

Şekil 22. Çalışma alanından alınan su örneklerinin ABD Tuzluluk Laboratuvarl diyagramındaki dağılımı [5].

Tarsus Ovası'ndan alınan örneklerin \%51'i ile Yüreğir Ovası'ndan alınan örneklerin \%28'i C3S1 sinıfina giren, fazla tuzlu ve az sodyumlu sular olup, sodyuma karşı duyarlı olan bitkiler dışında, drenaj yapılmaksızın bitki sulama amaçlı kullanılamaz. Tarsus Ovası'ndan alınan örneklerin \%29'u ile Yüreğir Ovası'ndan alınan örneklerin \%37'si C2-S1 sinifina giren, orta tuzlulukta ve az sodyumlu sular olup, orta derecede tuza dayanıklı bitkilerin sulanmasında kullanılabilirler. Tarsus Ovası'ndan alınan örneklerin \%11'ini, Yüreğir Ovası'ndan alınan örneklerin \%12'sini oluşturan C3-S2 sinıfina giren fazla tuzlu, orta derecede sodyumlu olan sular, permeabilitesi iyi olan jipsli araziler için uygun olup drenaj yapılmaksızın bitkiler için kullanılamaz. Ovalardan alınan birkaç örnek C3-S4 sinıfına giren fazla tuzlu ve çok fazla sodyumlu sular olup sulama suyu olarak kullanıma uygun değildirler. Birkaç örnek C4S1 sınıfına giren çok fazla tuzlu ve az sodyumlu sular olup, sulama suyu olarak kullanıma uygun değildir, ancak drenajın çok iyi sağlandığı yerlerde bitkiler yetişebilir. Bunların dışında bölgede, C2-S2 sinıfına giren, orta tuzlulukta ve orta derecede sodyumlu sular da mevcut olup bunlar orta derecede suya ihtiyaç duyan bitkiler için kullanılabilir niteliktedirler. Ayrıca üç örnek C3-S3 sinıfina giren fazla tuzlu ve fazla sodyumlu su sinifinda olup, ender hallerde sulama suyu olarak kullanılabilirler. Yüreğir Ovası'ndan alınan iki örnek C2-S3 sinıfina giren orta tuzlulukta ve fazla sodyumlu sular olup ender hallerde sulama suyu olarak kullanılabilirler. Yüreğir Ovası'ndan alınan C4S2, C4-S3 ve C4-S4 sinifina giren sular sulamada kullanılamazlar.

Nehirlerden (Berdan ve Seyhan) alınan su örneklerinin SAR değerleri 0,43-1,37 arasında, EC değerleri ise $344-626 \mu \mathrm{S} / \mathrm{cm}$ arasında değişmektedir. C2-S1 sınıfına giren bu sular, orta derecede tuza dayanıklı bitkilerin sulanmasında kullanılabilirler (Şekil 22).

Kanallardan alınan su örneklerinin SAR değerleri 0,53-3,37, EC değerleri ise 438-1262 $\mu \mathrm{S} / \mathrm{cm}$ arasında değişmektedir. Alınan örneklerin \%77'si C2-S1 sinıfina girmektedir. $\mathrm{Bu}$ sular orta derecede tuza dayanıklı bitkilerin sulanmasında kullanılabilirler. Suların \%23'ü ise C3-S1 sinifina giren fazla tuzlu ve az sodyumlu sular olup, sodyuma karşı duyarlı olan bitkiler dışında, drenaj yapılmaksızın bitkiler için kullanılamazlar (Şekil 22).

Çalışma alanından alınan yeraltı ve yüzey sularının sulama suyu olarak kullanılabilirliği ayrıca Wilcox diyagramı yardımıyla değerlendirilmiştir (Şekil 23). Tarsus Ovası'ndan alınan W15 nolu örneğin ve Yüreğir Ovası'ndan alınan W78 nolu örneğin elektriksel iletkenlik değerleri $(\mathrm{EC}>4000 \mu \mathrm{S} / \mathrm{cm})$ yüksek olduğu için bu su örnekleri Wilcox diyagramına yerleştirilememiştir. Tarsus Ovası'ndan alınan örneklerin \%36'sı, Yüreğir Ovası'ndan alınan örneklerin ise \%39'u "çok iyi-iyi”" sınıfındadır. Tarsus Ovası'ndan alınan örneklerin \%40'1, Yüreğir Ovası'ndan alınan örneklerin ise $\% 25$ ' $i$ "iyi-kullanılabilir" sinifindadır. Tarsus Ovası'ndan alınan örneklerin \%12'si, Yüreğir Ovası'ndan alınan örneklerin \%14'ü "kullanılabilir-şüpheli" sınıfındadır. Tarsus Ovası'ndan alınan örneklerin geri kalan \%12'si ile Yüreğir Ovası'ndan alınan örneklerin \%16's1 "şüpheli-kullanılamaz" sınıfındadır. Yüreğir Ovası'ndan alınan örneklerin geriye kalan $\% 6$ 'lık kismı ise "kullanılamaz" sinıfina girmektedir.

Nehirlerden (Berdan ve Seyhan) alınan örnekler ile kanallardan alınan örneklerin \%81'i “çok iyiiyi" sinıfina, kanallardan alınan örneklerin $\% 19$ 'u ise "iyi-kullanılabilir" sinıfina girmektedir (Şekil 23). 


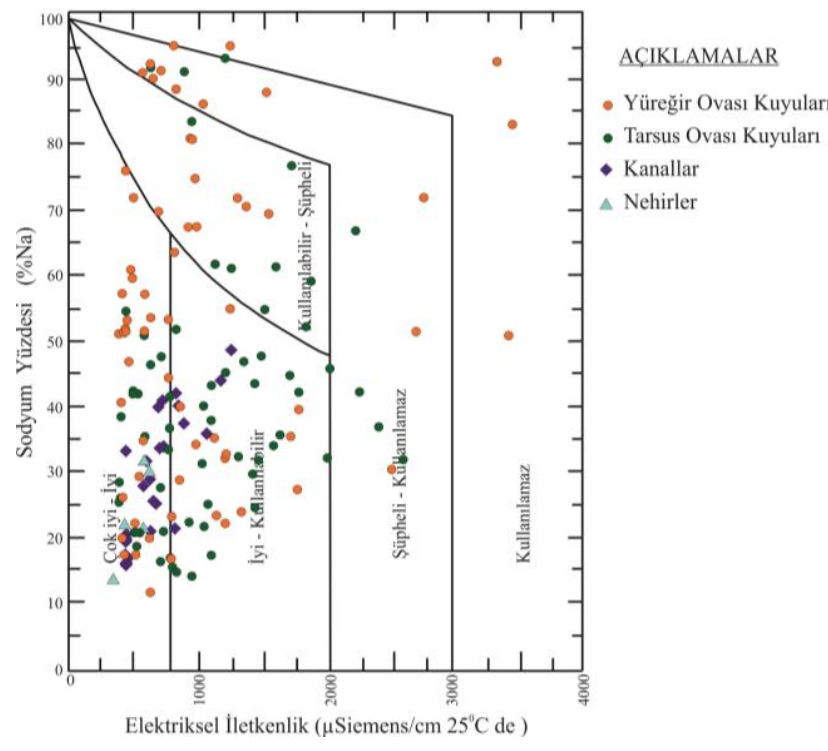

Şekil 23. Çalışma alanından alınan su örneklerinin Wilcox diyagramındaki dăğlımı [5].

\section{Sonuçlar}

Çukurova Deltası'nın büyük bir kısmını kapsayan Aşağı Seyhan Ovası'nın yeraltı ve yüzey üstü su kalitesinin belirlenmesi amaciyla Haziran-Temmuz 2014'te bölgedeki mevcut sı̆̆ kuyulardan ve yüzey sularından toplam 173 adet su örneği alınmıştır. Alınan örneklerde çeşitli fizikokimyasal parametrelere ait ölçümler yapılmıştır. Elde edilen veriler, oluşturulan çeşitli diyagramlar (Piper, Durov, Yarı Logaritmik Schoeller, ABD Tuzluluk Laboratuvarı ve Wilcox) kullanılarak değerlendirilmiştir.

Oluşturulan Piper diyagramları incelendiğinde; Tarsus Ovası'ndan alınan yeraltı suyu örnekleri ile nehirlerden ve kanallardan alınan örneklerin çoğunun karbonat sertliğinin \%50'den fazla olan, toprak alkalilerin $\left(\mathrm{Ca}^{+2}+\mathrm{Mg}^{+2}\right)$ alkalilerden $\left(\mathrm{Na}^{+}+\mathrm{K}^{+}\right)$, zayıf asit köklerinin $\left(\mathrm{CO}_{3}{ }^{-2}+\mathrm{HCO}_{3}{ }^{-}\right)$ de güçlü asit köklerinden $\left(\mathrm{SO}_{4}{ }^{-2}+\mathrm{Cl}^{-}\right)$daha fazla olduğu su sinıfinda olduğu, Yüreğir Ovası'ndan alınan örneklerin ise iyonların hiçbirinin \%50'yi geçmediği, karışık tip sular sınıfinda olduğu gözlenmiștir. Akdeniz ve lagünlerden alınan sular ise $\mathrm{NaCl}$ su tipindedir.

Oluşturulan Durov diyagramlarında, bir noktadan alınan yeraltı suyu örneği haricindeki diğer örneklerin TÇM miktarlarının ve $\mathrm{pH}$ değerlerinin yaklaşık olarak birbirine yakın olduğu gözlenmiştir. Diyagramlar incelendiğinde Akdeniz'den ve lagünlerden alınan suların ana katyonunun $\mathrm{Na}^{+}$, anyonunun ise $\mathrm{Cl}^{-}$olduğu, nehirlerden ve kanallardan alınan örneklerin katyonlar açısından hâkim iyonlarının değişken olduğu, anyonlar açısından ise hâkim iyonun $\mathrm{HCO}_{3}{ }^{-}$olduğu gözlenmiştir.

Çalışma alanından alınan yeraltı suyu örnekleri için oluşturulan Yarı Logaritmik Schoeller diyagramında benzer kökenli, aynı hazneye ve beslenme alanına sahip olan suların benzer pik değerler verdiği, dolaşım sürecinin fazla olması nedeniyle aynı akiferde dolaşan diğer sulara göre bazı iyonlarca farklı miktarda zenginleşen suların ise benzer paralelliğe sahip olmadığ gözlenmiştir. Akdeniz'den ve lagünlerden alınan örneklerin benzer özellikler taşıdıkları gözlenirken, nehirlerden alınan örnekler ile kanallardan alınan bazı örneklerde $\mathrm{Ca}^{+2}$ ve $\mathrm{Na}^{+}+\mathrm{K}^{+}$içeriklerinin diğer örneklere göre farklılıklar gösterdiği gözlenmektedir.

Çalışma alanından alınan yeraltı sularının sulama suyu açısından değerlendirilebilmesi için oluşturulan ABD Tuzluluk Laboratuvarı diyagramında suların C2-S1, C2-S2, C2-S3, C3S1, C3-S2 C3-S3, C3-S4, C4-S1, C4-S2, C4-S3 ve C4-S4 sinıflarında yer aldığ 1 ve birkaç su örneği haricinde alınan örneklerin sulama suyu olarak kullanılabileceği gözlenmiştir. Ayrıca nehirlerden alınan örnekler ile kanallardan alınan örneklerin büyük bir kısmının C2-S1 sınıfina giren sular olduğu ve orta derecede tuza dayanıklı bitkilerin sulanmasinda kullanılabileceği gözlenmiştir. Suların sulama suyu olarak kullanılabilirliğinin belirlenmesinde kullanılan diğer bir diyagram ise Wilcox diyagramıdır. $\mathrm{Bu}$ diyagrama göre yeraltı suları "çok iyi-iyi”, "iyi-kullanılabilir”, "kullanılabilirşüpheli”, "şüpheli-kullanılamaz" ve "kullanılamaz" sinıflarında yer almaktadır. Nehirlerden alınan örnekler ile kanallardan alınan örneklerin büyük bir kısmı "çok iyi-iyi" sınıfında, kanallardan alınan örneklerin geri kalan kısmı ise "iyi-kullanılabilir" sınıfında yer almaktadır.

\section{Teşekkür}

$\mathrm{Bu}$ çalışma, Mersin Üniversitesi Bilimsel Araştırma Projeleri Koordinatörlüğü tarafindan 
FBE JMB (CA) 2012-5 DR numaralı proje kapsamında desteklenmiştir.

\section{Kaynaklar}

[1] A. Davraz, Y. Bal, F. Aksever ve S. Varol, "Şuhut (Afyonkarahisar) Batısı Su Kaynaklarının Hidrojeoloji ve Hidrojeokimyasal İncelemesi”, (Süleyman Demirel Üniversitesi Fen Bilimleri Enstitüsü Dergisi), Sayı 2, 2019.

[2] C. Başaran, "Afyon Kocatepe Üniversitesi-Ans Kampüsü (Afyonkarahisar) Yeraltısularının Hidrojeokimyası ve Kullanılabilirlik Özelliklerinin Belirlenmesi”, (Mühendislik Bilimleri ve Tasarım Dergisi), Say1 2, 2019.

[3] Ş. Şener ve H. Kibar, "Karagöl (Borçka-Artvin) Gölü ve Çevresinin Hidrojeokimyasal İncelemesi”, (Jeoloji Mühendisliği Dergisi), Say1 41, 2017.

[4] F. G. Piga, N. G. R. Tão, M. H. Ruggiero, D. S. Marquezola, W. L. O. Boina, C. W. C., J. A. Lollo, R. Lorandi, E. A. Melanda and L. E. Moschini, "Multi-criteria Potential Groundwater Contamination and Human Activities: Araras watershed, Brazil", (Revista Brasileira de Recursos Hídricos Brazilian Journal of Water Resources), Vol 56, 2017.

[5] Akbulut Can, "Aşağ1 Seyhan Ovası (Adana) yeraltı ve yüzey suyu kaynaklarının hidrojeolojisi ve hidrojeokimyası”, Doktora Tezi, Mersin Üniversitesi Fen Bilimleri Enstitüsü, Mersin, 2016.

[6] A. Yüceer ve N.G. İnkayalı, "Aşağı Seyhan Nehri Su Kalitesi Değişiminin QUAL2E Modeli ile İncelenmesi”, Araştırma, (Su Kirlenmesi Kontrolü Dergisi), Sayı 3, 2004.

[7] Seyran Zeki, “Aşağ1 Seyhan Ovasının geçmişten günümüze arazi kullanımındaki değişiminin, coğrafi bilgi sistemleri ve uzaktan algilama ile belirlenmesi”, Yüksek Lisans Tezi, Çukurova Üniversitesi Fen Bilimleri Enstitüsü, Adana, 2009.

[8] Soyak Aslıhan, “Aşağı Seyhan Ovası sulama sistemlerindeki yabanc1 otlanma ve yabanc1 ot türleri ile üzerindeki doğal düşmanların saptanması", Çukurova Üniversitesi Fen Bilimleri Enstitüsü, Yüksek Lisans Tezi, Adana, 2009.

[9] G. Aslan, G. Tumbat, S. Soyupak, C. Yurteri, “Aşağı Seyhan Havzasında Besin Maddesi Taşınımı", Turkish Journal of Engineering and Environmental Sciences, Say1 23, 1999.

[10] A.K. Onur, E. Ekemen, S. Soyupak ve C. Yurteri, "Management strategies for the Lower Seyhan Catchment", Say1 10, 1999.

[11] G. Öğrünç, K. Gürbüz ve A. Nazik, "Adana Baseni Üst Miyosen-Pliyosen İstifinde Messiniyen Tuzluluk Krizine Ait Bulgular", (Hacettepe Üniversitesi Yerbilimleri Uygulama ve Araştırma Merkezi Bülteni), Sayı 22, 2000.

[12] F, Taraf, M. Eren ve K. Gürbüz, "Karaisalı Formasyonu'nun (Adana Baseni-Türkiye) Fasiyes ve Mikrofasiyes Özellikleri”, Türkiye Jeoloji Bülteni, Say1 3, 2013.

[13] G. Schmidt, "VII. Adana Petrol Bölgesinin Stratigrafik Nomenklatürü”, (Petrol Dergisi), Sayı 6, 1961.

[14] M. N. Yalçın, “Adana Havzası'daki Petrol ve Doğal Gazın Kökeni”, Türkiye 7. Petrol Kongresi, 427-434, (1987).
[15] Taşkaya Zeynep, “Adana havzası (Yenice-Karaisal1/Adana) Miyosen yaşlı istiflerinin yeraltı jeolojisi ve hazne kaya özelliklerinin incelenmesi”, Yüksek Lisans Tezi, Çukurova Üniversitesi Fen Bilimleri Enstitüsü, Adana, 2005.

[16] Maden Tetkik ve Arama Enstitüsü (MTA), Adana, 1:500.000 Jeoloji Haritas1, Ankara, 2002.

[17] M. Şenol, S. Kapur ve Ş. Şahin, "Adana havzası Kuvaterneri”, İ.T.Ü. Maden Fak. Türkiye Kuvaterneri Workshop Bildiri Özleri, İstanbul, 24-27, (1993).

[18] Dinçer Ayşegül, “Aşağı Seyhan Ovası (ASO)'nda su kaynaklarının geliştirilmesi ile lagünlerin ilişkisi”, Yüksek Lisans Tezi, Çukurova Üniversitesi Fen Bilimleri Enstitüsü, Adana, 2007.

[19] Ö. Özbay, M. Z. L. Göksu ve M. T. Alp, "Bir Akarsu Ortamında (Berdan Çayı, Tarsus-Mersin) En Düşük ve En Yüksek Akım Dönemlerinde Bazı Fiziko-Kimyasal Parametrelerin İncelenmesi", (Frrat Üniversitesi Fen Bilimleri Dergisi), Say1 1, 2011.

[20] Temelsu Uluslararası Mühendislik Hizmetleri A.Ş., Seyhan Havzası Master Plan Ara Raporu, Adana, 2011.

[21] A. Yaşar, G. Abasıkeleş ve N. Yalçın, "Adana ilinin arazi kullanım potansiyeli”, MTA Genel Müdürlüğü, 10239, Ankara, (1999).

[22] A.M. Piper, "Interpretation of Water Analyses", Geological Survey Water Resources Division No.12., 1979.

[23] S.A. Durov, "Natural Waters and Graphic Representation of Their Compositions", Akademiya Nauk SSSR Doklady 59, 87-90, 1948.

[24] H. Schoeller, "Les Eaux Souterraines, Hydrologie Dynamique et Chimique", Recherche, Exploitation et Évaluation des Ressources. 187 fig. Paris: Masson et Cie, Éditeurs. 642 p. NF 105, 1962.

[25] United States Salinity Laboratory Staff (USSLS), "Diagnosis and Improvement of Saline and Alkali Soils", United States Department of Agriculture, Handbook 60, 160 pp, 1954.

[26] L.V. Wilcox, "The Quality of Water for Irrigation Use", US Department of Agriculture Technology Bulletin 962, Vol. 40, Washington DC., 1948. 